\title{
КРИМІНАЛЬНА ВІДПОВІДАЛЬНІСТЬ ЗА ОКРЕМІ РІЗНОВИДИ ПРОПАГАНДИ
}

\author{
ПІСНИЙ Б.М. - кандидат економічних наук, доцент, директор філії \\ Европейського університету \\ ПАСЕМЧУК С.С. \\ Свропейського університету \\ ГОРБАЛЬ О.В. - \\ Европейського університету \\ студент магістратури, юридичний факультет \\ студент магістратури, юридичний факультет
} DOI 10.32782/EP.2021.4.14

У статті розглядаються питання кримінальної відповідальності за окремі різновиди пропаганди. Констатовано, що право на свободу думки і слова, на вільне вираження свойх поглядів і переконань є невід'ємним конституиійним правом людини і громадянина, яке включає можливість вільно збирати, зберігати, використовувати і поширювати інбормаиію усно, письмово або в інший спосіб - на свій вибір.

Втім ие право може бути обмежене в $і$ тересах начіональної безпеки, територіальноі иілісності або громадсъкого порядку з метою запобігання заворушенням чи злочинам, для охорони здоров'я населення, для захисту репутаиіӥ або прав інших людей, для запобігання розголошенню інформачї, одержаної конбідениійно, або для підтримання авторитету $i$ неупередженості правосуддя. А тому особа, яка пропагує до вчинення діянь, що є кримінально-караними, таким виходить за межі наданого їй права.

Встановлено, що публічні заклики мають інформачійний характер, тобто передають відповідну інформацію, яка повинна бути конкретизована $i$ відображати кримінально-протиправний характер дій. Такі заклики адресовані широкому колу осіб та їх зміст повинен бути доведений до свідомості громадян 3 метою схиляння останніх до вчинення кримінальних протиправних дій.

Ключові слова: пропаганда, заклик, публічність, публічні заклики, інформаційна дія.

\section{Постановка проблеми}

Право на свободу думки і слова, на вільне вираження своїх поглядів і переконань 6 невід'ємним конституційним правом людини і громадянина, яке включає можливість вільно збирати, зберігати, використовувати i поширювати інформацію усно, письмово або в інший спосіб - на свій вибір (п.1 ст.34 Конституції України). Втім Основним Законом України встановлені певні обмеження щодо реалізації цього права в інтересах національної безпеки, територіальної цілісності або громадського порядку з метою запобігання заворушенням чи злочинам, для охорони здоров'я населення, для захисту репутації або прав інших людей, для запобігання розголошенню інформації, одержаної конфіденційно, або для підтримання авторитету i неупередженості правосуддя (п.2 ст.34 Конституції України).А тому особа, яка пропагує до вчинення діянь, що є кримінально-караними, таким виходить за межі наданого їй права.

Дещо схожі положення також передбачені у Міжнародному пакті про громадянські і політичні права від 16 грудня 1966 р., відповідно до якого кожна людина має право на вільне вираження свого погляду незалежно від державних кордонів, усно, письмово чи за допомогою друку або художніх форм чи іншими способами на свій вибір. Водночас користування передбаченими правами накладає особливі обов'язки і особливу відповідальність. Воно може бути пов'язане з певними обмеженнями, які мають встановлюватися за- 
коном і бути необхідними: а) для поваги прав і репутації інших осіб; б) для охорони державної безпеки, громадського порядку, здоров'я чи моральності населення (ст.19).

3 огляду на це у КК України передбачена ціла низка норм, які власне встановлюють кримінально-правову заборону пропаганди кримінально-протиправної ідеології, а саме: ч. 2 ст. 109 «Публічні заклики до насильницької зміни чи повалення конституційного ладу або до захоплення державної влади», ст.110 «Публічні заклики на умисні дії, вчинені з метою зміни меж території або державного кордону України на порушення порядку, встановленого Конституцією України», ст.258-2 «Публічні заклики до вчинення терористичного акту», ст.299 «Публічні заклики до вчинення дій, що мають ознаки жорстокого поводження 3 тваринами», ст.436 «Публічні заклики до агресивної війни або до розв'язування воєнного конфлікту», ч. 2 ст.442 «Публічні заклики до геноциду». М.Б. Стиранка з цього приводу зазначає, що криміналізація законодавцем зазначених дій обумовлена необхідністю присікти вже на ранніх стадіях готовність інших осіб до вчинення більш рішучих кроків, зокрема безпосереднього посягання на зміну меж території або державного кордону України [1, с.109]. Втім наскільки ці норми є ефективними - питання не вивчене.

\section{Стан теоретичного дослідження}

Питанням кримінальної відповідальності за окремі різновиди пропаганди присвячена чимала кількість праць, що є свідченням актуальності та важливості розглядуваної тематики. Зокрема, мова йде про наукові дослідження О.Ф. Бантишева, С.Ф. Денисова, I.В. Діордіци, О.О. Дудорова, З.А. Загиней, О.М. Костенка, С.В. Ааби, С.М. Мохончука, В.О. Навроцького, А.А. Музики, Х.В. Олійник, М.А. Рубащенка, О.В. Шамари та інших. Також не можна не згадати про дисертаційні дослідження тих авторів, які присвячені проблемним аспектам кримінально-правової протидії кримінально-протиправній ідеології, а саме: М.Б. Стиранки («Кримінально-правова характеристика сепаратизму в Україні», Аьвів, 2021 р.), А.В. Мошняги («Кримінальна відповідальність за злочини проти конституційних основ національної безпеки України», м. Харків, 2011 р.), А.О. Данилевського («Кримінальна відповідальність за матеріальне, організаційне чи інше сприяння створенню або діяльності терористичної групи чи терористичної організації», м. Київ, 2009 р.). Внесок зазначених науковців $\epsilon$ неоціненний, втім досі чимало питань не втрачають своєї гостроти та $\epsilon$ недостатньо дослідженими, зокрема, щодо відмежування публічних закликів від підбурювання чи розповсюдження; щодо визначення кількісної характеристики публічності тощо.

\section{ВикАад основних положень}

Передусім слід з'ясувати, що треба розуміти під поняттям «заклик». Відповідно до великого тлумачного словника української мови це поняття розглядається як звернення до певної групи людей, у якому в стислій формі висловлено провідну ідею часу, політичну вимогу, завдання; прохання, вимога розгорнути яку-небудь діяльність, певним чином поводити себе [2, с. 395]. Натомість, поняття «публічний» трактують як такий, що відбувається в присутності публіки, людей; призначений для широкого користування, громадський [2, c. 930].

Що стосується поняття публічних закликів, то у теорії кримінального права загалом погляди щодо їх трактування збігаються. Так, O.С. Стеблинська під ним розуміє активний вплив відкрито звернений з використанням магнітофона, радіо, телебачення, інших технічних засобів тощо) на невизначену кількість людей (слухачів, читачів, глядачів) або на членів певної партії, організації чи інше угрупування, пов'язаний зі схиленням їх до здійснення погромів, підпалів, знищення майна, захоплення будівель чи споруд [3, с.274]. Дещо схожу позицію займає О.В. Епель, вважаючи, що публічні заклики передбачають відкрите звернення до невизначеного або до значного кола осіб, у якому висловлюються ідеї, погляд чи вимоги, спрямовані на те, щоб шляхом поширення їх серед населення чи його окремих категорії схилити певну кількість осіб до певних злочинних дій [4]. У свою чергу,B.В. Гапончук зауважує, що основною властивістю публічних закликів 6 лінгвістичне маніпулювання, якому притаманні: цілеспрямований вплив одного суб'єкта на іншого (інших); 


\section{Кримінальне право, кримінальний процес та криміналістика}

однонаправленість такого впливу; відбувається під час спілкування; має на меті змінити когнітивну та (або) поведінкову діяльність іншої (інших) особи (осіб) [5, с.194].

У подальшому необхідно зупинитись на аналізі ознак поняття «публічні послуги». Так, першою їх ознакою є те, що вони мають інформаційний характер, тобто передають відповідну інформацію, яка повинна бути конкретизована і відображати кримінально-протиправний характер дії. Так, скажімо, заклик на кшталт «Нам потрібно боротися, проявити свою громадянську позицію, не дозволити владі маніпулювати нами» не слід розцінювати як публічні заклики до насильницької зміни чи повалення конституційного ладу або до захоплення державної влади.

У той же час судовій практиці відомо чимало випадків притягнення до кримінальної відповідальності за публічні заклики до вчинення злочинних дій. Один із таких відображений у вироку Харківського районного суду Харківської області від 23 липня 2018 р. Так, $\mathrm{B}$, діючи умисно, будучи активним учасником «антимайданівських» спільнот, де розповсюджуються матеріали, що дестабілізують соціально-політичну обстановку в регіоні, розпалюють ворожнечу до «української нації», закликають до утворення замість Ауганської та Донецької областей непередбачених законодавством України територіальних одиниць: Луганської та Донецької народних республік відповідно, та до їх одностороннього визнання як незалежних державних утворень, тобто до зміни меж території України шляхом створення за рахунок вказаних областей інших незалежних держав на порушення порядку, встановленого Конституцією України без проведення всеукраїнського референдуму, передбаченого ст.73 Конституції України, використовуючи наявну у іï розпорядженні особисту сторінку в соціальній мережі «Вконтакте», доступну для огляду необмеженому колу користувачів систематично розміщувала інформацію сепаратиського та антидержавного характеру.

Реалізовуючи злочинний умисел, направлений на зміну меж території та державного кордону України у спосіб, не передбачений Конституцією України, 04 березня 2014 року та 05 квітня 2014 року, В., на особистій сторінці в соціальній мережі «В Контакте» розмістила у вигляді репосту з назвою «Новороссия, вставай - мы обязаны победить!!!».

Відповідно до висновку спеціаліста за результатами проведеного дослідження у стенограмі розміщеного у вигляді репосту містяться наявні заклики до вчинення дій, спрямованих на зміну меж території або державного кордону України в порушення порядку, встановленого Конституцією України, а саме: «05 марта 15-16 часов по всем областям юго-востока акция неповиновения бандеровской чуме, что засела в Киеве и собирается оттуда давить нас в наших городах, поселках и селах! Донбасс, Одесса, Харьков, Херсон, Николаев, Запорожье, Днепропетровск, Кривой Рог, Крым хватит кормить всяких бандеровских галыцян, волынчан, черновчан, хватит кормить бандеровский Киев. Сейчас, когда экономика той Украины идет к краху. Когда каждый из нас на своей шкуре и каждый из наших близких ощутит безнадежье, нищету и голод, которое наступит очень скоро. Бандеровская хунта в Киеве решила назначить воров олигархов в наших областях, чтобы они воровали, и часть денежных средств отсылать в Киев и западенцам на их прикорм. Хватит, пора заканчивать с этим. Или они нас, или мы их!!!». Згідно з висновком експерта у цьому фрагменті містяться зневажливо-образливі висловлювання про «всяких бандеровских галыцян, волынчан, черновчан» та «бандеровский Киев». Державну владу в Україні називають «Бандеровская хунта в Києве». Автором тексту здійснюється антитетичне протиставлення західноукраїнських регіонів і «юго-востока», здійснюється підбурення населення до непокори та відкритого протистояння «западенцам», проголошуючи при цьому «по всем областям юго-востока акцию неповиновения бандеровской чуме, что засела в Киеве и собирается оттуда давить нас в наших городах, поселках и селах!!!». За характером вказані заклики є публічними, за формою прямими.

В об'єктивному змісті висловлювань, виражених у формі прямих публічних закликів,Ю з одного боку, автор спотворює сучасні державні реалії, а з іншого - не визнає державного статусу України. При цьому робиться спроба і підмінити назви держави, i залякати вторгненням військ на територію 
України, що безпосередньо містить семантику закликів до вчинення дій, спрямованих на зміну меж територій України та державного кордону України на порушення порядку, встановленого Конституцією України. Таким чином, В. фактично здійснила розповсюдження матеріалів із закликами до вчинення умисних дій, направлених на зміну меж території або державного кордону України на порушення порядку, встановленого Конституцією України [6].

Наступною ознакою публічних закликів $\epsilon$ те, що вони повинні бути адресовані широкому колу осіб. Тобто вони характеризуються суб'єктним складом, до якого входять: особа, яка висловлює відповідну протиправну інформацію (адресант публічних закликів), та особи, які сприймають відповідну інформацію (адресати публічних закликів) [5, с.217]. Відповідно звернення, яке закликає громадян до вчинення певних кримінальних протиправних дій, повинне бути спрямоване до невизначеного їх кола. Мабуть, чи не найбільш дієвим засобом донесення інформації до громадян із використанням засобів масової інформації, зокрема, Інтернету, преси, телебачення. Не випадково, законодавець в окремих складах кримінальних правопорушень цю ознаку передбачив як кваліфікуючу (ч.3 ст.109, ч.2 ст.258-2, ч.2 ст.436-1 КК України).

У п.63 Рішення Європейського суду з прав людини (Справа «Редакція газети «Правоє дело» та Штекель проти України» (Заява № 33014/05) вказується, що Інтернет як інформаційний і комунікаційний інструмент дуже відрізняється від друкованих засобів масової інформації, особливо у тому, що стосується здатності зберігати та передавати інформацію. Електронна мережа, яка обслуговує мільярди користувачів у всьому світі, не $є$ і потенційно не буде об'єктом такого ж регулювання та засобів контролю. Ризик завдання шкоди здійсненню та використанню прав людини і свобод, зокрема права на повагу до приватного життя, який становлять інформація з Інтернету та комунікація в ньому, є, безумовно, вищим, ніж ризик, який походить від преси [7].

У судовій практиці України також мають місце випадки вчинення публічних закликів із використанням 3МІ. Так, Ю., перебуваючи в будівлі Ауганської обласної ради, вико- ристовуючи канал «LIFE NEWS», виступила зі заздалегідь підготовленою промовою, у якій проголосила публічні заклики до насильницької зміни конституційного ладу в Україні, а саме: «Мы также готовим референдум об независимости, либо, так сказать, автономии Ауганской области...». Відповідно до даних висновку судово-лінгвістичної експертизи, у фрагментах виступу обвинуваченого містилися публічні заклики до таких дій, як підготовка до референдуму щодо автономії Ауганської області, що може призвести до змін територіального устрою України [8].

Ще однією ознакою публічних закликів $\epsilon$ те, що їх зміст повинен бути доведений до свідомості громадян. Їх метою є здійснення певного впливу на людей з використанням вербальних та невербальних засобів [9, с. 125]. Врешті-решт, останньою їх ознакою, яка випливає з попередньої, є безпосереднє схиляння громадян до вчинення кримінальних протиправних дій, а саме, до терористичного акту, геноциду, ведення агресивної війни тощо.

Публічні заклики необхідно відрізняти від підбурювання до вчинення кримінального правопорушення. Власне ключовою розмежувальною їх ознакою є публічність, оскільки при підбурюванні до протиправних дій схиляється конкретний адресат, тоді як при публічних закликах звернення адресоване широкому (невідомому) колу осіб. Відповідне розмежування достатньо повно здійснено B.B. Гапончуком, який власне виокремлює п'ять розмежувальних ознак, а саме: 1) при публічних закликах протиправна діяльність суб'єкта кримінального правопорушення не обов'язково повинна бути вдалою. Тоді як підбурювання як закінчена дія характеризується лище успішним впливом на іншу особу, що виявляється в обов'язковому вчиненні нею того кримінального правопорушення, до якого іiі схиляють; 2) якщо протиправні дії є абстрактними, то це свідчить про публічні заклики, тоді як підбурювання стосується схиляння до вчинення конкретного (конкретних) правопорушення (правопорушень); 3) публічні заклики мають місце тільки у випадку публічності, тоді як підбурювання з урахуванням наявності двостороннього суб'єктивного зв'язку між двома особами (між тією, яка схиляє, та тією, яку схиляють до вчинення кримінально- 
го правопорушення) зазвичай характеризується індивідуальністю, оскільки спрямовано на вчинення персоніфікованого кримінального правопорушення; 4) підбурювання належить до співучасті у вчиненні кримінального правопорушення, то і особа, яка схиляє, i особа, яку схиляють, повинні характеризуватися обов'язковими ознаками суб'єкта кримінального правопорушення. Що стосується публічних закликів, то далеко не завжди всі адресати повинні бути суб'єктами кримінальних правопорушень (наприклад, малолітні чи недієздатні); 5) підбурювання може стосуватися будь-якого умисного кримінального правопорушення, тоді як кримінальна відповідальність за публічні заклики настає лише у випадках, спеціально передбачених у статтях Особливої частини КК України [5].

\section{Висновки}

Таким чином, публічні заклики мають інформаційний характер, тобто передають відповідну інформацію, яка повинна бути конкретизована і відображати кримінально-протиправний характер дії. Такі заклики адресовані широкому колу осіб та їх зміст повинен бути доведений до свідомості громадян 3 метою схиляння останніх до вчинення кримінальних протиправних дій.

\section{入ітература}

1. Стиранка М.Б. Кримінально-правова характеристика сепаратизму в Україні: дис. канд. юрид. наук. Спец.: 12.00.08 - кримінальне право та кримінологія; кримінально-виконавче право. Аьвівський державний університет внутрішніх справ. Аьвів. 2021 р. 259 с.

2. Великий тлумачний словник української мови (з дод. і допов.). / уклад. і голов. ред. В. Т. Бусел. Київ; Ірпінь : ВТФ «Перун», 2007. 1736 с.

3. Кримінальне право. Особлива частина / О.С. Стеблинська. - К. : Ін-т крим.-викон. служби, 2014. 358 с.

4. Епель О.В. Об'єктивні ознаки публічних закликів до вчинення терористичного акту. Форум права. 2011. № 1. С. 329-334. Режим доступу: http://nbuv.gov.ua/UJRN/FP_index. htm_2011_1_55

5. Гапончук В.В. Кримінально-правова протидія публічним закликам до вчинення злочинних дій: дис. канд. юрид. наук. Спец.:
The article considers criminal responsibility for certain types of propaganda. It is stated that the right to freedom of opinion and expression, to express freely their views and opinions is an inalienable constitutional right of a person and a citizen, which includes the possibility to freely collect, preserve, use and disseminate information in oral, written or otherwise - to his or her choice.

However, this right may be limited in the interests of national security, territorial integrity or public order in order to prevent theft or crime, to protect the health of the population, to protect the reputation or rights of other people, to prevent disclosure of information obtained in a confidential manner, or to maintain the authority and impartiality of justice. And that is why the person who propagates to the act of the girl, who is criminalpunishable, thus goes beyond the limits of the right granted to her.

It has been established that public appeals are informational in nature, that is, transmit relevant information, which should be concrete and reflect the criminal-illegal nature of the action. Such appeals addressed to a wide range of people and their content should be brought to the public's consciousness with the aim of approving the latter to commit criminal illegal actions.

Key words: propaganda, appeal, publicity, public appeals, information action.

12.00.08 - кримінальне право та кримінологія; кримінально-виконавче право. Інститут держави і права ім. В.М.Корицького. Київ. 2021 р. 259 c.

6. Вирок Харківського районного суду Харківської області від 23 липня 2018 р. https://reyestr.court.gov.ua/Review/75467243

7. Рішення Европейського суду 3 прав людини (Справа «Редакція газети «Правоє дело» та Штекель проти України» (Заява № 33014/05) https://zakon.rada.gov.ua/laws/ show/974_807\#Text

8. Вирок Шевченківського районного суду м. Києва від 2 липня 2014 р. Справа№ 761/18057/14-к. URL: http://reyestr.court.gov. ua/Review/39560563

9. Сидоренко Е. В. Аичностное влияние и противостояние чужому влиянию. Психологические проблемы самореализации личности. СПб. : СПбГУ, 1997. 216 с. 